\title{
PENGARUH KECERDASAN EMOSIONAL DAN LINGKUNGAN KELUARGA TERHADAP KINERJA GURU PENDIDIKAN KEWARGANEGARAAN SMA DI SULAWESI UTARA
}

\section{EFFECT OF EMOTIONAL INTELLIGENCE AND THE FAMILY ENVIRONMENT CITIZENSHIP EDUCATION TEACHER PERFORMANCE HIGH SCHOOL IN NORTH SULAWESI}

\author{
Apeles Lexi Lonto \\ Fakultas Ilmu Sosial.(FIS) \\ Universitas Negeri Manado \\ Email : apeleslexilonto@gmail.com
}

\begin{abstract}
Abstrak: Penelitian ini bertujuan untuk mengetahui pengaruh kecerdasan emosional dan lingkungan keluarga terhadap kinerja guru baik secara parsial maupun simultan. Penelitian ini adalah penelitian kuantitatif dengan mengunakan metode servei. Data dikumpulkan melalui angket dari 61 guru dan 183 siswa sebagai sampel yang pilih dengan teknik multistage sampling. Pengujian instrumen dengan uji validitas dan uji reliabilitas. Teknik analisis data yang digunakan adalah dianalisis secara deskriptif dan inferensial dengan analisis regresi dan korelasi berganda. Hasil pengujian hipotesis pertama diperoleh koefisien arah regresi $b_{1}=0,255$ dan nilai $t_{\text {hitung }}=$ 2,581 lebih besar dari nilai $t_{\text {tabel }}$ maka $\mathrm{H}_{\mathrm{O}}$ ditolak, ini berarti bahwa kecerdasan emosional berpengaruh positif terhadap kinerja guru. Hasil pengujian hipotesis kedua diperoleh koefisien arah regresi $\mathrm{b}_{2}=0,570$ dan nilai $\mathrm{t}_{\text {hitung }}=5,812$ lebih besar dari nilai $\mathrm{t}_{\text {tabel }}$ maka $\mathrm{H}_{\mathrm{O}}$ ditolak, ini berarti bahwa lingkungan keluarga berpengaruh positif terhadap kinerja guru. Hasil pengujian hipotesis ketiga diperoleh nilai $\mathrm{F}_{\text {hitung }}=1270,927$ lebih besar dari nilai $\mathrm{F}_{\text {tabel }}$ maka kecerdasan emosional dan lingkungan keluarga secara bersama-sama berpengaruh positif terhadap kinerja guru. Hasil ini menegaskan bahwa kinerja guru dapat ditingkatkan melalui peningkatan kecerdasan emosional dan kondusifnya lingkungan keluarga. Kedua variabel bebas tersebut saling melengkapi, memperkuat, memperkokoh dan mengoptimalkan kompetensi yang dibutuhkan untuk memaksimalkan kinerja guru.
\end{abstract}

Kata kunci: kecerdasan emosional, lingkungan keluarga, kinerja guru

\begin{abstract}
This study aims to determine the effect of emotional intelligence and family environment on the performance of teachers either partially or simultaneously. This research is a quantitative research using the method servei. Data were collected through questionnaires of 61 teachers and 183 students in the sample were selected with multistage sampling technique. Testing instruments to test the validity and reliability testing. Data analysis technique used was analyzed by descriptive and inferential analysis of multiple regression and correlation. The first hypothesis testing results indicate the direction of the regression coefficients $b 1=0.255$ and the value of $t=$ 2.581 bigger than t table thus, the $\mathrm{HO}$ is rejected, it means that emotional intelligence has positive influence on the performance of teachers. The second hypothesis analysis shows the direction of the regression coefficient $b 2=0.570$ and the value of $t=5.812$ bigger than $t$ tabel thus, the $H O$ is rejected, it means that the family environment has positive influence on the performance of teachers. The third hypothesis analysis results obtained value of $F=1270.927$ bigger than the value of $F$ table with Thus emotional intelligence and family environment together positive effect on the performance of teachers. This result confirms that teacher performance can be improved through increased emotional intelligence and conducive family environment. Both variables are complementary, reinforce, strengthen and optimize the competencies required to maximize the performance of teachers.
\end{abstract}

Keywords: emotional intelligence, family environment, the performance of teachers 


\section{PENDAHULUAN}

Guru adalah ujung tombak penentu kualitas pendidikan. Kinerja guru berpengaruh secara langsung terhadap kualitas pendidikan setiap peserta didik. Oleh sebab itu semakin baik kinerja guru maka akan semakin baik juga kualitas pendidikan yang dihasilkan. Demikian sebaliknya semakin buruk kinerja guru maka akan semakin buruk juga kualitas pendidikan yang dihasilkan.

Fokus pada peningkatan mutu dan profesionalisme guru dapat mendorong tercapainya pendidikan untuk semua termasuk didalamnya daerah-daerah terpencil dan kelompok masyarakat yang termarjinalkan (Direktur Organisasi Pendidikan, 2010). Profesionalisme guru yang dimaksudkan adalah bukan semata-mata persoalan keterampilan teknis, tetapi juga kepribadian guru sebagai sosok yang patut diteladani oleh peserta didik.

Di masa depan dibutuhkan guru yang mempunyai kreativitas, kritis, terbuka dalam masyarakat dan berpikir terhadap persoalan pendidikan yang ada. Kemam-puan tersebut oleh Daniel Goleman disebut dengan Emotional Intelligence atau kecerdasan emosi. Hasil penelitiannya menunjukkan bahwa kecerdasan emosi menyumbang $80 \%$ dari faktor penentu kesuksesan seseorang, sedang-kan $20 \%$ yang lain ditentukan oleh $I Q$ (Intelligence Quotient). Orang mulai sadar pada saat ini bahwa tidak hanya keunggulan intelektual saja yang diperlukan untuk mencapai keberhasilan tetapi diperlukan sejenis keterampilan lain seperti kecerdasan emosional untuk menjadi yang terdepan (Goleman, 2001:144). Hal ini merupakan suatu usaha untuk mengelola diri sendiri sebagai guru dalam melaksanakan tugasnya sebab terjadinya berbagai tindak kekerasan di sekolah, dimana ada guru yang memukul siswa, menciderai, menghukum tanpa rasa kemanusiaan menunjukkan rendahnya kecerdasan emosional guru.

Selain faktor kecerdasan emosional maka factor komunikasi interpersonal dalam lingkungan keluarga juga dapat mempengaruhi kinerja guru. Maksudnya disini bahwa lingkungan keluarga dalam situasi komunikasi antar anggota keluarga sering terjadi akibat kurangnya komunikasi antar keluarga. Tudingan karena kesibukan menjadi penyebab renggangnya komunikasi di antara anggota keluarga. Komunikasi interper-sonal sangat dibutuhkan dalam rangka membina hubungan keakraban dari hati ke hati.
Sesuai konteks yang dimaksudkan di atas, maka tugas guru PKn dengan jabatan profesional seyogyanya harus sejalan dengan itu sehingga dapat membina karakter bangsa berdasarkan budaya Pancasila. Permasalahan yang terjadi yaitu sungguh sangat ironis jika seorang guru PKn yang seharusnya menjadi teladan ternyata kurang mampu mengendalikan emosi, tidak menjadi teladan dalam membina hubungan baik dalam keluarga bahkan religiusitasnya buruk.

Fenomena kinerja guru PKn antara lain, pada umumnya guru yang terser-tifikasi kinerjanya sama dengan yang belum tersertifikasi, kualitas pengajaran masih konvensional dengan mengunakan cara mengajar yang bersifat direktif, pelaksanaa evaluasi dalam proses pembelajaran belum secara koprehensif dimana hanya menekan pada domain kognitif sedangkan pengajaran PKn berorintasi pada pengajaran afektif atau sikap. Kecerdasan emosional belum secara efektif mengelolah diri sendiri, kemampuan membangkitakan semangat dan motivasi kerja serta memiliki kemampuan menangani emosi ketika berhubungan dengan orang lain.

Berdasarkan uraian permasalahan tersebut maka kajian terhadap kinerja guru PKn menjadi sangat penting untuk diteliti dalam kaitannya dengan kecerdasan emosional dan lingkungan keluarga.

\section{Kajian Pustaka \\ Kinerja Guru}

Kinerja dalam bahasa Inggris perfor-mance diartikan sebagai unjuk kerja, pelaksanaan kerja, pencapaian kerja, hasil kerja atau unjuk kerja. Menurut Gomes kinerja merupakan catatan terhadap hasil produksi dari sebuah pekerjaan tertentu atau aktivitas tertentu dalam periode waktu tertentu. Kemudian menurut Winardi kinerja merupakan konsep yang bersifat universal yang merupakan efektivitas operasional suatu organisasi, bagian organisasi dan bagian karyawannya berdasar standar dan kriteria yang telah ditetapkan sebe-lumnya, karena organisasi pada dasarnya dijalankan oleh manusia, maka kinerja sesungguhnya merupakan perilaku manusia dalam memainkan peran yang mereka lakukan dalam suatu organisasi untuk memenuhi standar perilaku yang telah ditetapkan agar membuahkan tindakan dan hasil yang diinginkan (Sedamayanti, 2001:50). 
Sehubungan dengan itu maka kinerja guru merupakan faktor yang amat menentukan bagi mutu pembelajaran/ pendidikan yang akan berimplikasi pada kualitas output pendidikan setelah menyelesaikan sekolah. Berkenaan dengan kinerja guru sebagai pengajar, Uzer Usman (2005:16) mengemukakan 3 aspek kemampuan yang hendaknya dimiliki oleh guru yakni kemampuan personal, kemampuan profesional dan kemampuan sosial. Pada dasarnya kinerja guru merupakan kinerja atau unjuk kerja yang dilakukan oleh guru dalam melaksanakan tugasnya sebagai pendidik. Kualitas kinerja guru akan sangat menentukan kualitas hasil pendidikan.

Karakteristik guru yang baik adalah memiliki kesadaran akan tujuan, memiliki harapan akan keberhasilan bagi semua siswa, mentoleransi ambiguitas, menunjukkan kemauan beradaptasi dan berubah untuk memenuhi kebutuhan siswa, merasa tidak nyaman jika kurang mengetahui, mencerminkan komitmen pada pekerjaan mereka, belajar dari berbagai model, dan menikmati pekerjaan dan siswa mereka. Berkenaan dengan itu maka Melissa Kelly, menegaskan ada lima hal yang perlu dipertimbangkan oleh seorang guru, yaitu komitmen waktu, besarnya bayaran, apresiasi dan kewajaran, harapan masyarakat, dan komitmen emosional (Sudarwan, 2010:149151).

Selain hal-hal yang telah disebutkan di atas, seorang guru harus bersikap positif karena sikap positif merupakan aset besar dalam hidup. Guru akan melemparkan banyak pola kurva dalam hidup dan terutama dalam profesi mengajar. Sikap positif akan membantu guru mengatasi ini dengan cara terbaik. Selanjutnya, guru harus menjaga konsis-tensi dalam rangka untuk menciptakan lingkungan belajar yang positif karena siswa tahu apa yang diharapkan dari guru setiap hari. Seorang guru yang konsisten adalah orang yang dari hari ke hari sikap dan tindakannya sama. Guru juga harus memiliki rasa keadilan. Seorang guru yang adil memperlakukan setiap siswa sama dalam situasi yang sama. Selanjutnya, guru hendaknya memiliki keluwesan dan fleksibilitas. Salah satu prinsip pengajaran bahwa segala sesuatu harus dalam keadaan konstan berubah. Interupsi dan gangguan adalah normal, dan guru harus siap memodifikasi perilaku dan sikap itulah pilihan yang benar.

Kinerja guru atau unjuk kerja merupakan hasil yang dicapai oleh guru dalam melaksanakan tugas-tugas yang dibebankan kepadanya yang didasarkan atas kecakapan, kemudian pengalaman dan kesungguhan serta penggunaan waktu. Kinerja guru akan baik jika guru telah melaksanakan unsur-unsur keseti-aan dan komitmen yang tinggi pada tugas mengajar. Kinerja seorang guru dilihat dari sejauh mana guru tersebut melak-sanakan tugasnya dengan tertib dan bertanggung jawab, kemampuan menggerakkan dan memotivasi siswa untuk belajar dan kerjasama dengan teman sejawat guru. Kinerja guru sebagai seperangkat perilaku nyata yang ditunjukkan oleh guru pada waktu kegiatan memberikan pelajaran kepada siswanya.

\section{Kecerdasan Emosional}

Kecerdasan emosional merupakan dua kata yang memiliki makna tunggal. Oleh sebab itu pada bagian ini akan dipaparkan secara satu demi satu, kemudian digabungkan menjadi suatu konsep yang bermakna tunggal.

Kata kecerdasan merupakan istilah umum untuk menggambarkan "kepin-taran" atau "kepandaian" seseorang (Munandir, 2001:122). Suharsono (2003:43) menyebutkan bahwa kecerdasan adalah kemampuan untuk meme-cahkan masalah secara benar, yang secara relatif lebih cepat dibandingkan dengan usia biologisnya. Gardner dalam Rose (2002:58) mengemukakan bahwa kecerdasan adalah kemampuan untuk memecahkan masalah atau menciptakan suatu produk yang bernilai dalam satu latar belakang budaya atau lebih.

Pendapat dari Suharsono dan Gardner di atas menyebutkan bahwa kecerdasan merupakan suatu kemam-puan individu untuk memecahkan masa-lahnya. Jika Suharsono menilai kecer-dasan dari sudut pandang waktu, semen-tara Gardner menilainya dari sudut pandang tempat. Definisi dari Suharsono dan Gardner berbeda dengan definisi dari Amstrong dimana menurut beliau, kecerdasan merupakan kemampuan untuk menangkap situasi baru serta kemampuan untuk belajar dari pengalaman masa lalu seseorang. 
Kecerdasan bergantung pada konteks, tugas serta tuntutan yang diajukan oleh kehidupan kita dan bukan tergantung pada nilai IQ, gelar dari perguruan tinggi atau reputasi bergengsi. Untuk itu ia memerlukan kemampuan untuk mengu-asai diri dengan lingkungannya demi kelestarian hidupnya. hidupnya bukan hanya untuk kelestarian pertumbuhan, tetapi juga untuk perkembangan priba-dinya. Karena itu manusia harus belajar dari pengalamannya (Dalyono, 1997: 182).

Sehubungan beberapa pengertian tentang kecerdasan yang telah dikemu-kakan di atas maka dapat dikatakan bahwa kecerdasan adalah kemampuan seseorang untuk memberikan solusi terbaik dalam penyelesaian masalah yang dihadapinya sesuai dengan kondisi ideal suatu kebenaran. Selanjutnya mengenai arti emosi. Emosi dalam bahasa Latin misalnya dijelaskan sebagai motus anima yang arti harfiahnya berarti jiwa ang menggerakkan kita (Cooper dan Sawaf, 2002:4). Akar kata emosi adalah movere, kata kerja Bahasa Latin yang berarti "menggerakkan, bergerak" (Goleman, 2001:7).

Emosi mempunyai peran dalam peningkatan proses konstruksi pikiran dalam berbagai bentuk pengalaman kehidupan manusia. Salovey dan Mayers mendefinisikan emosi sebagai respon terorganisasi, termasuk sistem fisiologis, yang melewati berbagai batas subsistem psikologis, misalnya kognisi, motivasi, dan pengalaman (Wahyono, 2001:37). Pengertian ini menunjukkan bahwa emosi merupakan respon atas stimulus yang diperoleh dari lingkungan sekitar yang terorganisasi dengan baik yang melewati sub-sistem psikologis.

Setelah pengkajian kata kecerdasan dan kata emosional maka gabungan kedua kata tersebut menjadi kecerdasan emosional, dapat dikemukakan berikut ini seperti Gardner adalah orang yang pertama kali mengungkapkan adanya kecerdasan lain selain akademik yang dapat mempengaruhi keberhasilan sesorang. Kecerdasan lain itu disebut dengan emotional intelligence atau kecerdasan emosi (Goleman, 2001:51).

Kecerdasan emosi merupakan kemampuan untuk menggunakan emosi secara efektif dalam mengelola diri sendiri dan mempengaruhi hubungan dengan orang lain secara positif. Menurut Salovey dan Mayer kecerdasan emosi adalah kemampuan untuk merasakan emosi, menerima dan membangun emosi dengan baik, memahami emosi dan pengetahuan emosional sehingga dapat meningkatkan perkembangan emosi dan intelektual.

Selain itu Salovey juga memberikan definisi dasar tentang kecerdasan emosi dalam lima wilayah utama yaitu, kemam-puan mengenali emosi diri, mengelola emosi diri, memotivasi diri sendiri, mengenali emosi orang lain, dan kemampuan membina hubungan dengan orang lain. Seorang ahli kecerdasan emosi yakni Goleman mengatakan bahwa yang dimaksud dengan kecerdasan emosi di dalamnya termasuk kemampuan mengontrol diri, memacu, tetap tekun, serta dapat memotivasi diri sendiri. Kecakapan tersebut mencakup penge-lolaan bentuk emosi baik yang positif maupun negatif.

\section{Lingkungan Keluarga}

Dalam kehidupan sehari-hari seseorang akan selalu berinteraksi dengan ling-kungan. Lingkungan tersebut dapat berupa lingkungan keluarga, lingkungan sekolah dan masyarakat. Pengalaman yang diperoleh baik yang didengar, dilihat maupun yang dialami seringkali berpengaruh kuat terhadap perubahan perilaku dan prestasi orang tersebut.

Pengertian lingkungan adalah segala sesuatu yang ada di sekitar manusia yang memengaruhi perkembangan kehidupan manusia baik langsung maupun tidak langsung. Lingkungan adalah jumlah semua benda hidup dan mati serta seluruh kondisi yang ada didalam ruang yang kita tempati. Menurut Munib secara umum lingkungan diartikan sebagi kesatuan ruang dengan semua benda, daya, keadaan dan makhluk hidup, termasuk manusia dan perilakunya yang mempengaruhi kelangsungan perikehi-dupan dan kesejahteraan manusia serta makhluk hidup lainya. Sedangkan ling-kungan pendidikan adalah berbagai faktor yang berpengaruh terhadap pendidikan atau berbagai lingkungan tempat berlangsungnya proses pendidikan (Asih, 2007:31-32).

Keluarga berasal dari bahasa Sansekerta yakni "kula" dan "warga" atau "kulawarga" yang berarti "anggota" "kelompok kerabat". Keluarga adalah lingkungan dimana beberapa orang yang masih memiliki hubungan darah, bersatu. Keluarga inti (nuclear family) terdiri dari ayah, ibu, dan anak-anak mereka. Keluarga adalah kelompok sosial kecil yang umumnya terdiri atas ayah, ibu dan anak yang mempunyai hubungan sosial relatif tetap dan didasarkan atas ikatan darah, perkawinan dan atau adopsi Ahmadi dalam Asih (2007:32). Batasan dari Departemen Kesehatan RI, Keluarga adalah unit terkecil dari 
masyarakat yang terdiri atas kepala keluarga dan beberapa orang yang terkumpul dan tinggal di suatu tempat di bawah suatu atap dalam keadaan saling ketergan-tungan.

Dari beberapa pandangan yang telah dikemukakan, ternyata keluarga memi-liki beberapa karakteristik antara lain: (a) Terdiri dari dua atau lebih individu yang diikat oleh hubungan darah, perka-winan atau adopsi. (b) Anggota keluarga biasanya hidup bersama atau jika berpisah mereka tetap memperhatikan satu sama lain. (c) Anggota keluarga berinteraksi satu sama lain dan masing-masing mempunyai peran sosial. (d) Mempunyai tujuan; menciptakan dan mempertahankan budaya, meningkatkan perkembangan fisik, psikologis dan sosial anggota. Dengan demikian dapat dinya-takan bahwa keluarga sangat berperan dalam aktualisasi kehidupan seseorang. Lingkungan keluarga memiliki peranan yang sangat penting bagi penyadaran, penanaman, dan pengembangan nilai. Keluarga merupakan perangkat utama perasaan yang terpadu antara sifat mengayomi dari orang tua dan sifat diayomi pada anak. Pendidikan dalam keluargalah merupakan pendidikan nilai yang paling hakiki karena berlangsung sejak anak berada dalam kandungan sampai anak meninggal dunia.

\section{Pengaruh Kecerdasan Emosional terhadap Kinerja Guru}

Kinerja pada dasarnya merupakan unjuk kerja seseorang dalam melaksanakan tugas dan tanggungjawabnya yang telah ditetapkan terlebih dahulu. Kinerja guru adalah kemampuan guru dalam melak-sanankan tugas yang dapat meningkatkan hasil kerja guru dalam melak-sanakan tugasnya mendidik, mengajar dan melatih. Seperti yang dikemukakan oleh Jusuf Enoch, kinerja guru sebagai pengelolaan pengajaran mempunyai beragam fungsi, tetapi fungsi yang paling umum adalah sebagai pencapaian fungsi perencanaan, pelaksanaan, dan evaluasi.

Menurut Goleman, resep untuk memperlihatkan kinerja yang menonjol dan sukses dipersyaratkan memiliki kecakapan dan kekuatan yang tersebar secara merata di bidang kecerdasan emosional. Kemampuan kecerdasan emosinal tersebut adalah: (1) Mandiri, masingmasing menyumbangkan secara unik kepada performa kerja; (2) Saling kertergantungan, masing-masing sampai batas tertentu memerlukan hal-hal tertentu pada yang lain, dengan interaksi yang banyak dan intensif; (3) Hierarkis, kecerdasan emosional membentuk ba-ngunan yang bertingkat. Kesadaran diri penting untuk pengaturan diri dan empati, pengaturan diri dan kesadaran diri ikut membangun motivasi, keempat kecakapan yang pertama ini membentuk keterampilan social (Goleman, 1999:40-41).

Solovey dan Mayer mengungkapkan bahwa kecerdasan emosional merupakan kemampuan mengelolah emosi dalam diri sendiri, mengekspresikan serta mengendalikan emosi, memiliki kepeka-an terhadap kata hati, untuk digunakan dalam menggali hubungan dengan orang dan melakukan tindakan sehari-hari.

Kemampuan guru membawa diri ditengah masyarakat dapat mempe-ngaruhi penilaian masyarakat terhadap guru. Guru harus bersikap sesuai dengan norma-norma yang berlaku di masya-rakat, responsive dan komunikatif terhadap masyarakat, toleran dan menghargai pendapat mereka. Dalam hal ini guru harus memiliki kecerdasan emosional yang baik untuk meningkatkan kinerja dalam bekerja.

Guru yang memiliki kemampuan yang tinggi dalam mengelolah emosi, mampu melaksanakan tugasnya sebagai pendidik, pengajar, fasilitator, moderator, pembimbing belajar bagi siswa. Sebaliknya guru yang kurang mampu mengendalikan emosi akan mengalam kesulitan dalam kinerjanya. Jelaslah disini bahwa diduga kecerdasan emosional berpengaruh positif terhadap kinerja guru.

\section{Pengaruh Lingkungan Keluarga terhadap Kinerja Guru}

Kinerja adalah proses kerja dari seseorang individu untuk mencapai hasil-hasil tertentu. Penampilan kerja (performance) diartikan sebagai ungkap-an kemampuan yang didasari oleh pengetahuan, sikap, keterampilan dan motivasi dalam menghasilkan sesuatu.

Keluarga adalah unit terkecil dari masyarakat yang terdiri atas kepala keluarga dan beberapa orang yang terkumpul dan tinggal di suatu tempat di bawah suatu atap dalam keadaan saling ketergantungan (Departemen Kesehatan RI). Secara sosio-kultural, lingkungan mencakup segenap stimulasi, interaksi dan kondisi eksternal dalam hubung-annya dengan perlakuan ataupun karya orang lain. Pola hidup keluarga, per-gaulan kelompok, pola hidup masyara-kat, latihan, belajar, pendidikan penga-jaran, bimbingan dan penyuluhan, adalah termasuk bagian lingkungan keluarga (Soemanto, 2006:85).

Dalam lingkungan keluarga terjadi interaksi yang dapat berpengaruh langsung maupun tidak langsung terhadap aktivitas kehidupan anggota 
keluarga. Keluarga harus membangun pendidikan nilai dalam lingkungan keluarga atau dalam rumah sebagai area pembelajaran nilai.

Sikap guru terhadap pekerjaan maupun dalam bentuk motivasi kerja yang ditampilkan guru yang memiliki sikap positif terhadap pekerjaan, sudah tentu menampilkan kepuasan yang baik terhadap pekerjaannya. Seseorang dipengaruhi oleh faktor internal yaitu fisiologis dan psikologis serta faktor eksternal yang berupa situasi yang dihadapi individu. Salah satu faktor eksternal yang mempengaruhi sikap seseorang adalah lingkungan keluarga. Oleh karena itu, guru yang berada dalam lingkungan keluarga yang harmonis akan menampilkan sikap yang baik, mengasihi siswa, menghargai siswa memberikan bimbingan dengan kasih sayang melindungi siswa agar tidak terjerumus pada perbuatan yang tidak bermoral dan tercela.

Kinerja guru yang berasal dari lingkungan keluarga yang baik selalu ditandai dengan sifatsifat positif. Mengembangkan nilai-nilai kehidupan keluarga yang positif seperti bekerja dengan senang hati, menunjukkan keteladanan dalam berbuat baik, memi-liki komitmen yang tinggi, memiliki kesadaran dan displin yang tinggi, berkolaborasi dan membimbing siswa, selalu melindungi siswa agar tidak terjerumus pada perbuatan tercela. Berdasarkan uraian di atas maka diduga lingkungan keluarga berpengaruh positif terhadap kinerja guru.

\section{Hipotesis Penelitian}

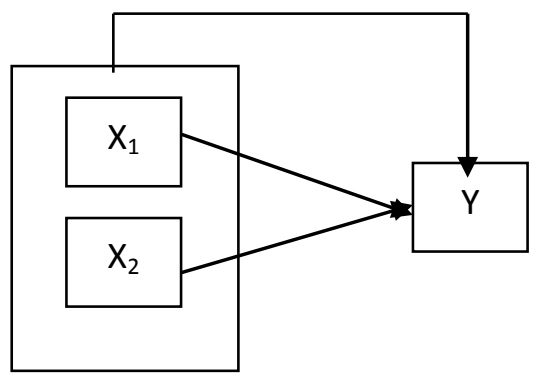

\section{Keterangan:}

$\mathrm{X} 1$ : Kecerdasan emosional

$\mathrm{X} 2$ : Lingkungan keluarga

$\mathrm{Y}$ : Kinerja Guru

1. Kecerdasan emosional berpengaruh positif terhadap kinerja guru

2. Lingkungan keluarga berpengaruh positif terhadap kinerja guru

3. Kecerdasan emosional dan lingkungan keluarga secara simultan berpengaruh positif terhadap kinerja guru

\section{Metodologi}

Penelitian ini adalah penelitian eksplanasi (explanatory research), yakni menganalisis dan menjelaskan pengaruh variabel-variabel yang ada di dalam model konsep penelitian. Metode penelitian yang digunakan adalah metode survey.

Penelitian ini dilaksanakan pada SMA di provinsi Sulawesi Utara. Populasi penelitian ini adalah guru yang mengajar Pendidikan Kewarganegaraan (Guru PKn) di SMA se Provinsi Sulawesi Utara yang tersebar pada 11 kabupaten dan 4 kota yaitu sebanyak 200 guru PKn. Penarikan sampel dilakukan dengan multistage, yaitu tahap pertama dipilih berdasarkan karakteristik daerah dima-na lokasi sekolah tempat guru PKn mengajar, yaitu Kota Manado sebagai daerah dimana Ibu Kota Provinsi berada, Kabupaten Minahasa dan Kota Bitung mewakili daerah di pinggiran Ibu Kota Provinsi, Kabupaten Bolaang Mongon-dow mewakili daerah yang jauh dari Ibu Kota Provinsi dan Kabupaten Sangihe dipilih untuk mewakili kabupaten daerah kepulauan. Tahap kedua, yaitu dipilih SMA Negeri dan SMA Swasta yang terakreditasi di setiap daerah yang ditetapkan pada tahap pertama. Tahap ketiga adalah menentukan guru yang mengajar PKn di sekolah yang terpilih pada tahap ketiga sebagai unit sampel dan diperoleh sebanyak 61 guru PKn sebagai unit analisis dan responden.

Teknik pengumpulan data dilakukan dengan mengunakan instrumen angket atau kuesioner. Instrumen penelitian yang disusun untuk masingmasing variabel menggunakan skala pengukuran yaitu skala Likert. Teknik analisis data yang digunakan adalah teknik analisis statistik deskriptif dan inferensial dengan menggunakan analisis regresi berganda.

\section{Hasil Penelitian dan Pembahasan Hasil Penelitian}

Hasil analisis data menunjukkan bahwa variabel Kecerdasan Emosional mempu-nyai nilai ratarata (Mean) sebesar 90,93 Median (Me) sebesar 91 dan modul (Mo) sebesar 91,00. Disamping itu, variabel Kecerdasan Emosional memiliki skor tertinggi 112 dan skor terendah 72 serta rentang 40. Distribusi data skor variabel Kecerdasan Emosional menunjukkan bahwa terdapat 24 (39\%) responden memiliki skor Kecerdasan Emosional yang berada pada kategori sedang, 35 $(58 \%)$ berada pada kategori tinggi, $2(3 \%)$ berada pada kategori sangat tinggi, sedangkan pada kategori sangat rendah dan rendah tidak ada $(0 \%)$. 
Hasil analisis data untuk variabel Lingkungan Keluarga mempunyai nilai rata-rata (Mean) sebesar 9486 Median (Me) sebesar 96 dan modul (Mo) sebesar 98. Disamping itu, variabel Lingkungan Keluarga memiliki skor tertinggi 114 dan skor terendah 75 serta rentang 39. Distribusi data skor variabel Lingkungan Keluarga menunjukkan bahwa terdapat $5(8 \%)$ responden berada pada kategori sedang, 39 (64\%) berada pada kategori tinggi, 17 (28\%) berada pada kategori sangat tinggi, sedangkan pada kategori sangat rendah dan rendah tidak ada $(0 \%)$.

Hasil analisis data untuk variabel Kinerja Guru mempunyai mempunyai nilai rata-rata (Mean) sebesar 196,06 Median (Me) sebesar 200 dan modul (Mo) sebesar 200. Disamping itu, variabel Kinerja Guru memiliki skor tertinggi 234 dan skor terendah 157. serta rentang 77. Distribusi data skor variabel Kinerja Guru menunjukkan bahwa terdapat $6(10 \%)$ responden memiliki skor Kinerja Guru yang berada pada kategori sedang, 41 (67\%) berada pada kategori tinggi, $14(23 \%)$ berada pada kategori sangat tinggi, sedangkan pada kategori sangat rendah dan rendah tidak ada $(0 \%)$.

Hasil analisis uji normalitas data variabel kinerja guru, kecerdasan emosional dan lingkungan keluarga seluruhnya berdistribusi normal.

Hasil analisis regresi berganda dapat dilihat pada tabel berikut:

\begin{tabular}{|l|c|c|c|c|c|}
\hline \multirow{2}{*}{ Model } & \multicolumn{2}{|c|}{$\begin{array}{c}\text { Unstandardized } \\
\text { Coefficients }\end{array}$} & $\begin{array}{l}\text { Standardized } \\
\text { Coefficients }\end{array}$ & \multirow{2}{*}{$\mathrm{t}$} & \multirow{2}{*}{ Sig } \\
\cline { 2 - 5 } & $\mathrm{B}$ & Std.error & Beta & & \\
\hline constant & - & 4.401 & - & 2.582 & .012 \\
\hline $\mathrm{X} 1$ & .456 & .177 & .255 & 2.581 & .012 \\
\hline $\mathrm{X} 2$ & 1.112 & .191 & .057 & 5.812 & .000 \\
\hline $\mathrm{Y}$ & \multicolumn{2}{|c|}{$\mathrm{R}_{\mathrm{y} 1,2,3}=0,993$} & \multicolumn{2}{|c|}{$\mathrm{R}_{\mathrm{y} 1,2,3}^{2}=0,985$} \\
\hline
\end{tabular}

Hasil analisis diperoleh koefisien arah regresi $\beta_{1}=0,255$ dan nilai $\mathrm{t}_{\text {hitung }}=2,581$ sedangkan nilai $\mathrm{t}_{\text {tabel }}$ pada $\alpha=0,05$ dengan $\mathrm{dk} 59$ $=1,67$ dan pada $\alpha=0,01=2,39$, maka $t_{\text {hitung }}>t_{\text {tabel. }}$ Dengan demikian maka $\mathrm{H}_{\mathrm{O}}$ ditolak, berarti bahwa Kecerdasan Emosional berpengaruh positif terhadap Kinerja Guru.

Hasil analisis diperoleh koefisien arah regresi $\beta_{3}=0,570$ dan nilai $\mathrm{t}_{\text {hitung }}=5,812$ sedangkan nilai $\mathrm{t}_{\text {tabel }}$ pada $\alpha=0,05$ dengan $\mathrm{dk} 59$ $=1,67$ dan pada $\alpha=0,01=2,39$ maka $t_{\text {hitung }}>t_{\text {tabel. }}$. Dengan demikian maka $\mathrm{H}_{\mathrm{O}}$ ditolak, ini berarti bahwa Lingkungan Keluarga berpengaruh positif terhadap Kinerja Guru.
Hasil pengujian secara simultan diperoleh nilai $F_{\text {hitung }}=1270,927$ sedangkan nilai $F_{\text {tabel }}$ pada $\alpha=0,05$ dengan $\mathrm{dk}$ pembilang $3 \mathrm{dan} \mathrm{dk}$ penyebut 57 diperoleh $=2,76$ dan pada $\alpha=0,01$ diperoleh $=1,13$, maka $F_{\text {hitung }}>F_{\text {tabel }}$. Dengan demikian kecerdasan emosional, dan lingkungan keluarga secara bersama-sama berpengaruh positif terhadap Kinerja Guru.

Disamping itu, diperoleh koefisien korelasi berganda sebesar $\mathrm{R}_{\mathrm{y} 1,2,3}=0,993$ yang berarti bahwa besarnya hubungan variabel Kecerdasan Emosional, dan Lingkungan Keluarga secara bersama-sama terhadap Kinerja Guru adalah $99,30 \%$. Nilai koefisien determinasi sebesar $R^{2}{ }_{y 1,2}$ $=0,985$ berarti bahwa 98,50\% Kinerja Guru ditentukan oleh Kecerdasan Emosional, dan Lingkungan Keluarga secara bersama-sama.

\section{Pembahasan}

Hasil pengujian hipotesis menunjukkan bahwa kecerdasan emosional berpe-ngaruh positif terhadap kinerja guru menunjukkan bahwa semakin baik kematangan emosional guru menye-babkan kinerja guru semakin meningkat. Karena kematangan emosional yang dimiliki guru menyebabkan guru lebih bijak dalam mengambil keputusan, memiliki kemampuan dalam berkomunikasi dengan banyak orang, dan memiliki rasa tanggungjawab moral tinggi terhadap pekerjaannya yang tentu akan meningkatkan kinerja dari guru.

Sebagai pemimpin dalam penge-lolaan proses pembelajaran, guru perlu memiliki kecerdasan emosional. Guru mampu mengendalikan dan meng-gerakkan secara optimal potensi kecer-dasan yang ada pada otak emosionalnya (limbic system) (Bahaudin, 2007:145). Dalam kaitannya dengan hubungan sosial sebagai indikator kecerdasan emosional, Gitosudarmo (2008:75) menegaskan bahwa kohesivitas merupakan kekuatan interaksi dari anggota suatu kelompok. Kohesivitas ditunjukkan dalam bentuk keramahtamahan antaranggota kelom-pok, mereka biasanya senang untuk bersama-sama. Masing-masing anggota merasa bebas untuk mengemukakan pendapat dan saran. Sedangkan kaitan-nya dengan empati, Devito (1997:260) menegaskan bahwa orang yang empatik mampu memahami motivasi dan pengalaman orang lain, perasaan dan sikap mereka, serta harapan dan keinginan mereka untuk masa mendatang.

Hasil pengujian hipotesis bahwa lingkungan keluarga berpengaruh positif terhadap kinerja guru dengan nilai $t_{\text {hitung }}(5,812)>t_{\text {tabel }}$ $(1,67)$ pada tingkat signifikansi $\alpha=0,05$. Hal ini 
menunjuk-kan guru yang berada dilingkungan keluarga yang baik akan menyebabkan kinerja guru semakin meningkat. Menu-rut Rivai dan Murni lingkungan keluarga merupakan faktor eksternal yang mempengaruhi sikap seseorang. Menu-rut Leke Iriany dalam Pasandaran mengemukakan bahwa Keluarga ber-fungsi untuk mendorong dan mengem-bangkan sikap agamis, menanamkan nilai-nilai budaya, cinta kasih, membe-rikan perlindungan bagi anggota keluarga. Kebutuhan ini merupakan syarat tumbuhnya manusia-manusia berkualitas. Karena guru berada dilingkungan keluarga yang harmonis dan berfungsi sebagaimana seharusnya maka guru akan menampilkan sikap yang baik, mengasihi siswa, menghargai siswa, memberikan bimbingan dengan kasih sayang, melindungi siswa agar tidak terjerumus pada perbuatan yang tidak bermoral. Sikap guru yang seperti ini mempengaruhi kinerja guru dalam menjalankan aktifitas kerjanya.

Ketiga, hasil pengujian hipotesis menunjukkan bahwa terdapat pengaruh positf kecerdasan emosional, dan lingkungan keluarga secara bersama-sama terhadap kinerja guru dengan $F_{\text {hitung }}(1270,927)$ lebih besar dari $F_{\text {tabel }}$ $(2,76)$ pada taraf signifikansi $\alpha=0,05$. Berpengaruh positif artinya bahwa semakin tinggi kecerdasan emosional, dan lingkungan keluarga maka semakin tinggi kinerja guru. Disamping itu bahwa kecerdasan emosional, dan lingkungan keluarga adalah faktor-faktor/variabel-variabel yang tidak dapat diabaikan dalam mempengaruhi kinerja guru. Hasil penelitian menunjukkan bahwa 98,50\% kinerja guru ditentukan oleh kecerdasan emosional, dan lingkungan keluarga secara bersama-sama. Menurut Stephen P. Robins "Performance is an evaluation of the results of a person's behavior. It involves determining how well of poorly a person has accomplished a task or done a job. Kinerja merupakan evaluasi terhadap hasil dari perilaku seseorang yang mencakup penetapan tentang seberapa baik dan buruknya seseorang telah menyelesaikan tugas atau pekerjaannya. Kecerdasan emosional merupakan kemampuan emosi secara efektif dalam mengelola diri sendiri memiliki kepekaan terhadap kata hati, untuk digunakan dalam menjalin hubungan dengan orang dan melakukan tindakan sehari-hari. Kinerja guru dipengaruhi oleh kecerdasan emosional, karena guru yang memiliki emosi yang stabil akan lebih bijak dalam mengambil keputusan, memiliki kemampuan berko-munikasi dengan orang lain, dan memi-liki rasa tanggung jawab moral tinggi untuk melaksanakan tugas sebagai pendidikan, pengajar, fasilitator, moderator dan pembimbing belajar bagi siswa.

Selain itu, kinerja guru juga tidak terlepas dari lingkungan keluarga dari guru yang bersangkutan. Karena lingkungan keluarga merupakan salah satu faktor eksternal yang mempe-ngaruhi sikap seseorang. Kinerja guru yang berasal dari lingkungan keluarga yang baik selalu ditandai dengan sifat-sifat positif seperti bekerja dengan senang hati, keteladanan dalam berbuat baik, disiplin, dan melindungi siswa agar tidak terjerumus pada perbuatan tercela. Dengan demikian kinerja guru dipengaruhi oleh faktor kecerdasan emosional dan lingkungan keluarga sehingga menurun atau meningkatnya kinerja guru dapat disebabkan oleh kematangan emosi dari guru serta keadaan lingkungan keluarga dari guru yang bersangkutan.

\section{Implikasi Penelitian}

Peningkatan kecerdasan emosional akan mempengaruhi kinerja guru. Seorang guru yang memiliki kestabilan emosi, dapat berkomunikasi dengan baik dan memiliki ketenangan dalam mengambil keputusan serta mengedepankan hati nurani dalam melaksanakan tugas sebagai guru yang professional.

Lingkungan keluarga yang kondusif dan harmonis akan meningkatkan ki-nerja guru. Suasana lingkungan keluarga dapat meningkatkan semangat kerja guru sehingga dalam pelaksanaan tugas guru dapat memaksimalkan potensi yang dimilkinya sehingga unjuk kerjanya semakin meningkat pula. Dengan adanya dukungan pihak keluarga serta terja-linnya komunikasi dan keterbukaan dalam berbagai aspek dapat meningkatkan intensitas kerja guru. Kinerja guru yang berasal dari lingkungan keluarga yang baik selalu ditandai sifat-sifat positif seperti bekerja dengan senang hati, keteladanan dalam berbuat baik, memiliki komitmen yang tinggi, dan memiliki kesadaran dan disiplin yang tinggi dalam menjalankan tugas

Kecerdasan emosional yang tinggi, dan lingkungan keluarga yang kondusif berpengaruh terhadap kinerja guru. Kekuatan kedua variabel bebas tersebut saling melengkapi, memperkuat, mem-perkokoh dan mengoptimalkan kompe-tensi yang dibutuhkan untuk memak-simalkan kinerja guru. Kecerdasan emosional berpotensi memaksimalkan kompetensi pedagogik, kepribadian, dan sosial. Selanjutnya lingkungan keluarga yang kondusif secara langsung mendukung penguatan kecerdasan emosional dan 
intensitas keberagamaan. Di dalam lingkungan keluarga yang kondusif guru dapat memelihara hubungan sosial yang baik mulai dari lingkungan terkecil sampai lingkungan yang lebih luas. Guru dapat berpartisipasi dalam kegiatan kemasyarakatan menjadi panutan dan tokoh masyarakat.

\section{Simpulan dan Saran Simpulan}

Berdasarkan hasil hasil penelitian dan pembahasan, maka dapat ditarik kesimpulan sebagai berikut: Pertama, Kecerdasan emosional berpengaruh positif terhadap kinerja guru, artinya jika kecerdasan emosional guru baik maka akan meningkatkan kinerja guru. Kedua, Lingkungan keluarga berpengaruh positif terhadap kinerja guru, artinya jika lingkungan keluarga yang kondusif akan meningkatkan kinerja guru.

Ketiga, Kecerdasan emosional, dan lingkungan keluarga secara bersama-sama berpengaruh positif terhadap kinerja guru, artinya jika kecerdasan emosional guru baik dan ditopang oleh kondusifnya lingkungan keluarga mereka, maka akan meningkatkan kinerja guru.

\section{Saran}

Proses rekruitmen guru tidak hanya mempertimbangkan kapasitas dan kapabilitas kecerdasan intelektualnya, tetapi harus juga mempertimbangkan kecerdasan emosional sebab tugas guru tidak hanya mengajar tetapi juga mendidik.

Pengembangan profesionalitas guru dilakukan melalui beberapa program, antara lain: peningkatan disiplin; peningkatan efesiensi dan efektifitas pembelajaran; peningkatan dan pengembangan kemampuan penguasaan meteri dan kemampuan pedagogic. Peningkatan budaya sekolah dalam hal penanaman nilai-nilai dan sikap keteladanan, yang dilaksanakan melalui interaksi guru-siswa.

\section{Pustaka Acuan}

Colin Rose dan Malcom J. Nicholl. 2002. Cara Belajar Cepat Abad XXI, penerjemah Dedy Ahimsa. Bandung: Nuansa

Direktur Organisasi Pendidikan, Ilmu Pengetahuan, dan Kebudayaan PBB (UNESCO). Kompas, 21 September 2010
Eni Asih. 2007. "Pengaruh Motivasi, Metode Pembelajaran, Lingkungan Sekolah, dan Lingkungan Keluarga Terhadap Prestasi Belajar”. Semarang

Goleman. 1999. Kecerdasan Emosi untuk Mencapai Puncak Prestasi. Jakarta: Gramedia Pustaka Utama

H. Veithzal Rivai dan Sylviana Murni, 2009. Education Management. Jakarta: Rajawali Pers

Indriyo Gitosudarmo. 2008. Perilaku Keorganisasian. Yogyakarta: BPFE

Joseph A. Devito. 1997. Human Communication, Alih Bahasa Agus Maulana, Jakarta: CPA

M. Dalyono. 1997. Psikologi Pendidikan Jakarta: Rineka Cipta

Munandir. 2001. Ensiklopedia Pendidikan. Malang: Um Press

Robert K. Cooper dan Ayman Sawaf. 2002. Executive EQ, penerjemah Alex Tri Kantjono Widodo. Jakarta: Gramedia Pustaka Utama

Sedarmayanti. 2001. SDM dan Produktivitas Kerja. Bandung: Mandar Maju

Sofyan S. Willis. 2009. Konseling Keluarga, Family Counseling. Bandung: Afabeta

Sudarwan Danim. 2010. Pedagogi, Andragogi, dan Heutagogi. Alfabeta: Bandung.

Suharsosno. 2003. Mencerdaskan Anak Depok: Inisiasi Press

Taufik Bahaudin. 2007. Brainware Leadership Mastery. Jakarta: PT Alex Media Komputindo

Tekad Wahyono, Memahami Kecerdasan Emosi Melalui Kerja Sistem Limbik, Indonesian Psychological Journal 
Universitas Wangsa Manggala Anima Uzer, Moh Usman. 2005. Menjadi Guru Surabaya Vol. 17, No.1 tahun 2001, h. 37

Profesional. Bandung:Remaja Rosdakarya Wasty Soemanto, 2006. Psikologi Pendidikan. Jakarta: Rinek 